\title{
Community Response to Government Policies at The Potential Landslide Area: The Case in Kuloprogo Regency
}

\author{
Syahrul Donie \\ Balai Penelitian Teknologi Kehutanan Pengelolaan DAS \\ Jl. A-Yani - Pabelan Kartasura - Surakarta \\ e-mail: syahruldonie@gmail.com
}

\begin{abstract}
The study examined the extent of community appreciation or response to government policies at the potential lanslide areas and the influencing reasons. By interviewing 35 representative informants, men and women, and divided into old, young and adult, then the data are analyzed and interpreted using the theory of action and the theory of symbolic. The results showed, the community, dominated by the farmer, were able to respond and deeply understood the government policies, particularly policies of spatial planning. This was indicated by the increasing knowledge of the community against areas that were prone to landslide and other sign that the region was going to experience a landslide. Almost all respondents said that they live in hilly areas prone to landslides, and they knew how to cope with and respond to these signs. However, government policy declaring that the community were expected to move from the area considered as dangerous was still lack of community's attention. This was due to the undersired experiences of the community in the new area which did not make their lives better, both in terms of livelihood as well as in terms of their social-culture life.
\end{abstract}

Keywords: landslide potential area, gevernment policies, community responses

\begin{abstract}
Abstrak
Penelitian ini melihat sejauh mana apresiasi atau respon masyarakat terhadap kebijakan pemerintah di daerah rawan longsor serta alasan-alasannya. Dengan mewawancarai 35 orang informan representatif, laki dan perempuan, yang dibagi menjadi tua, muda dan dewasa, data kemudian dianalisis dan diinterpretasikan menggunakan teori tindakan dan teori simbolik. Hasil penelitian menunjukkan bahwa masyarakat yang didominasi oleh masyarakat petani ini dapat merespon dan dapat memahami dengan baik kebijakan pemerintah, diantaranya kebijakan penataan tata ruang. Hal ini ditunjukkan oleh meningkatnya pengetahuan masyarakat akan daerah-daerah yang berpotensi longsor dan tanda-tanda daerah yang akan mengalami longsor. Hampir semua responden mengatakan bahwa mereka tinggal pada areal perbukitan yang rawan terhadap longsor, dan mereka tahu bagaimana mengatasi dan menyikapi tanda-tanda tersebut. Namun demikian, terhadap kebijakan untuk pindah dari daerah berbahaya tersebut masih sulit untuk diikuti oleh masyarakat, Hal ini disebabkan oleh pengalaman mereka dimana pada areal yang baru tidak membuat hidup mereka lebih baik, baik dari segi mata pencaharian maupun dari segi kehidupan bersosial budaya.
\end{abstract}

Kata kunci: daerah rawan longsor, kebijakan pemerintah, respon masyarakat

\section{Introduction}

Potential landslide areas are regions with geomorphologis phenomena (slopes, rocks, faults, inundations) prone to landslide, the movement of a land mass from one place to another from a small scale to a bigger scale which can burry a village (Marui, 1988; Hirnawan, 1994). Since these regions are prone to landslide, they can threaten people's lives and properties. Nevertheless, it is a fact that people who live in these regions are not few with their all of influencing reasons.

One or the region which had the most potential risk of landslide was Manoreh hill situated in Kulonprogo
Regency and the surrounding areas. In 2000, team of the Faculty of Geology Gajah Mada University had mapped that not less than 45 villages in that region were prone to landslides (Karnawati, 2003). These regions were dominated by some denudational hills with gully erotion, impermiabel rock layers and high intensity of rainfall (Pusat Studi Bencana Alam-UGM, 2001). Based on the data, these regions experienced landslides in every year that threathened people's lives and the loss of properties and other valuables (Hindaryoun, 2000).

To cope with the hazards of landslide, government of Kulonprogo Regency issued some policies: 1) policy of spatial planning, 2) policy of resident 
relocation and 3) policy of physical rehabilitation and prohibitation of annual crops (Pemerintah Daerah Kulonprogo, 2003).

The government of Kulonprogo Regency issued regional regulation no 1 year 2003 about the land use including resident houses. Samigalu District, where the research was conducted, was classified as an area of reservation both as an area with landslide potency and as a reservation for the subordinate areas. Obeying the law was an obligation for the citizens so that anyone who broke it would get legal sanctions. The government contributed for a landslide hazard mapping zone with a scale of 1:25000 for the local people and the policy of migration both translocal migration and transmigration. However, the fact showed that landslide caused a hazardous impacts to the people. The policies of physical rehabilitation and prohibition of planting annual corps particularly in sloping lands had been done for the people; nevertheless, some people still broke them. Sartohadi in his research (2008) stated that landslides in area of the research(Purworejo Regency) happened because of the people's activities; sloping cuts, mines and plants. Therefore, the aim of this research is to reveal community responses to government policies and the influencing reasons.

\section{Research Method}

\section{Time and Research Location}

This research was conducted in 2006 in Purwoharjo village, Samigaluh District, Kulonprogo Regency, Yogyakarta Province (Figure 1). Based on the

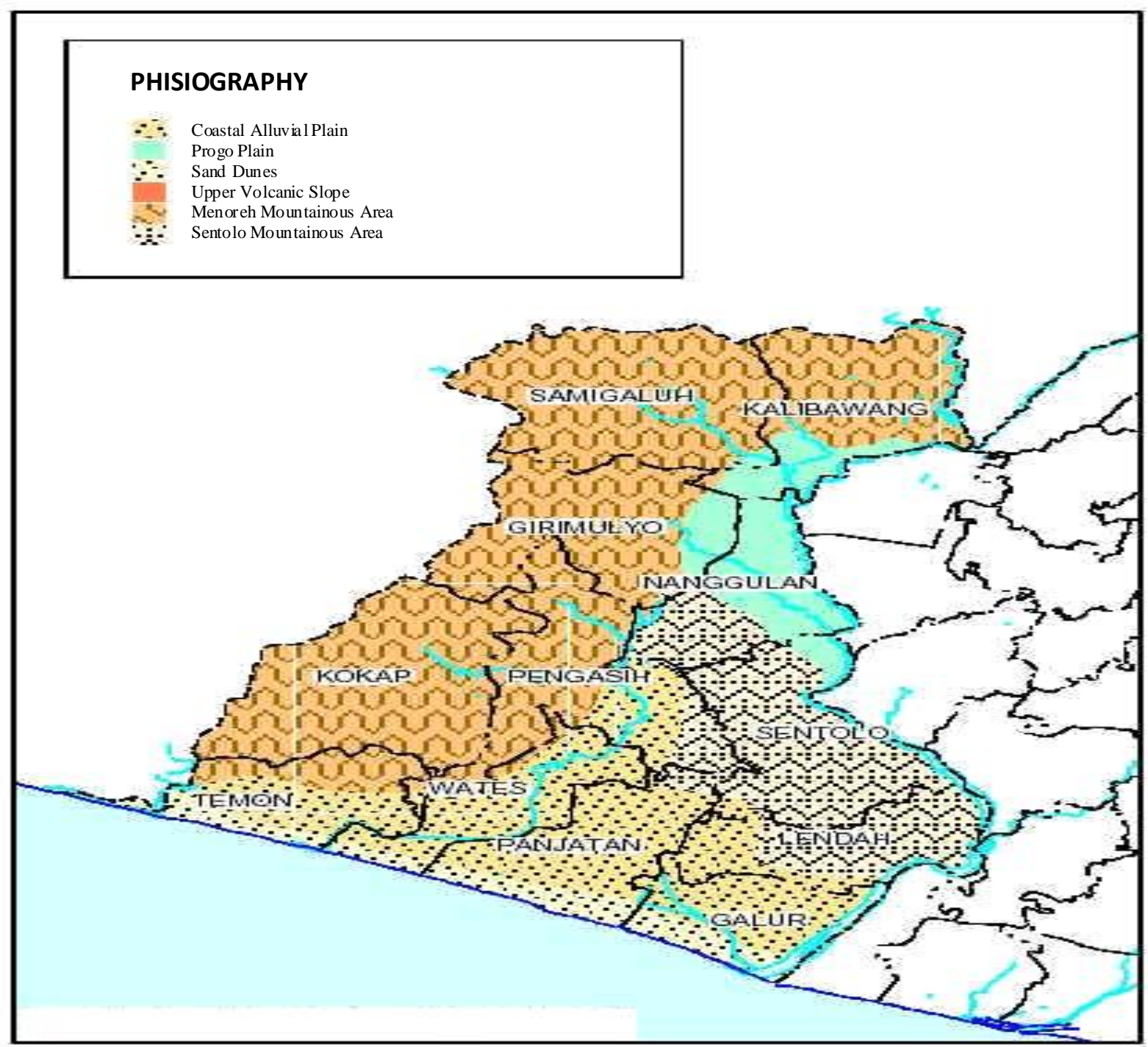

Figure 1. Reserach Area 
landslide hazard mapping zone from Center of Disaster Study of Gajah Mada University (PSBAUGM) in 2001, this village was classified as one of landslide potential areas where landslides happen annually . $90 \%$ of the people live in slopes which are pysically potential for landslides. Even in 2001 and 2002, a hazardous landslide happened and killed 9 and damaged 5 houses.

\section{Type of Research and Data Retrieval Technique}

This research is a qualitatif descriptif research so that the data are retrieved by some interviews. By interviewing 35 representative informants, men and women, and divided into old, young and adult, the data are retrieved and supported by observation and document analysis.

\section{Data Analysis}

The data, the answers of the informants added with the result of observation and several evidences, are analyzed and classified based on the aim of the research. They are supported by some documents and photos. Then, All of the phenomena and particular sympthons with the causes of the the sympthons are analyzed and interpreted.

\section{Result and Discussion}

\section{A brief Description of The Research Location}

Purwoharjo was a village in Samigaluh District, Kulonprogo Regency, Yogyakarta which was classified as a village from 7 villages having a high potency of hazardous landslides. This village was situated in $500 \mathrm{~m}$ above the sea, located on the left and right of the roads which connected Wates city or Yogyakarta city with Samigaluh district for approximately $35 \mathrm{~km}$ from Yogyakarta or $5 \mathrm{~km}$ from Wates and $5 \mathrm{~km}$ from the center of Samigaluh district.

As well as being easily accessible by private vehicle or public transportation, this village already had electricity; moreover, some houses including the village hall had telephone lines. As a village with easy access but prone to landslides, this place got many visits from some research and government institutions. Furthermore, it already had a potency and mitigation map of landslide with a relatively big scale of $1: 125,000$.

Based on manography data of the village (Anonimus, 2003), Purwoharjo village with the area of $925,071.5$ hectares had $30^{\circ}$ declivity, the thickness of weathering land less than $4 \mathrm{~m}$ and condition of the stones which was cut very often by fault structure. Population distribution were in areas with high declivity or hills prone to landslide. The area was dominated with the denosional hill type with gully erosion pattern and the difference between permeable and impermeable were so apparent. Furthermore, the permeable soil seemed laying on the impermeable soil. Therefore, a little force might lead to erosion. Distribution pattern of population could be seen on Figure 2 and Figure 3.

In research area, rainfall happened in a high intensity that was $2887 \mathrm{~mm} /$ year (type B according to Schmidt Ferguson) with the rainy days were 105 days/year

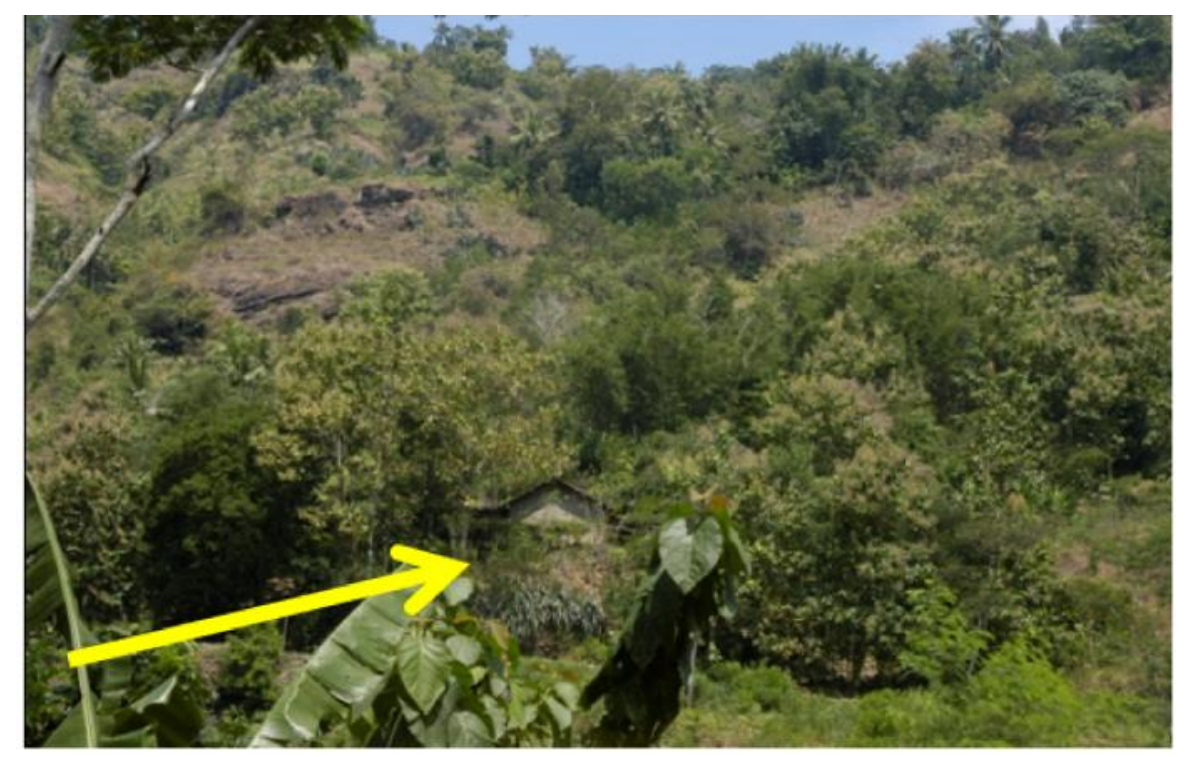

Figure 2. Houses Position in Landslide Area 
(PSBA-UGM, 2001). The high intensity of rainfall fulfilled the soil pores with water, passing through the soil until the impermeable layer and therefore it led to the daylight which finally moving the layer above it.

Generally land use were specified into $80 \%$ of dry land which included mixed garden and moorland and $20 \%$ of wetland which included rainfed agriculture. In dry land, farmers usually grew fruits such as rambutan, durian, mangosteen, jackfruit, coconut, clove, petai and mango, teak tree, lamtoro tree, mahogany tree, sengon tree, acacia tree, bamboo, whereas in wet land farmers usually grow rice, corn, bean, peanut, tobacco, cassava, and other annual crops.

Social and economical lives of people of Purworharjo Village with 4187 inhabitants or 865 heads of family were mostly famers $(69 \%)$, field labors $(8 \% 0$, enterpreneurs $(13 \%)$ and the rest were employees and others(10\%) (Anonimus, 2003). From the analysis data of village manography and the result of the interviews, it was shown that for each family they owned $6200 \mathrm{~m} 2$ with family income Rp. 1,010,667 per month which was from the result of dry land about Rp. 879,468, plantation crops Rp. 40,000 and from the field $\mathrm{Rp} 348,049$. It was a also a fact that the education of people was not in a good state that only

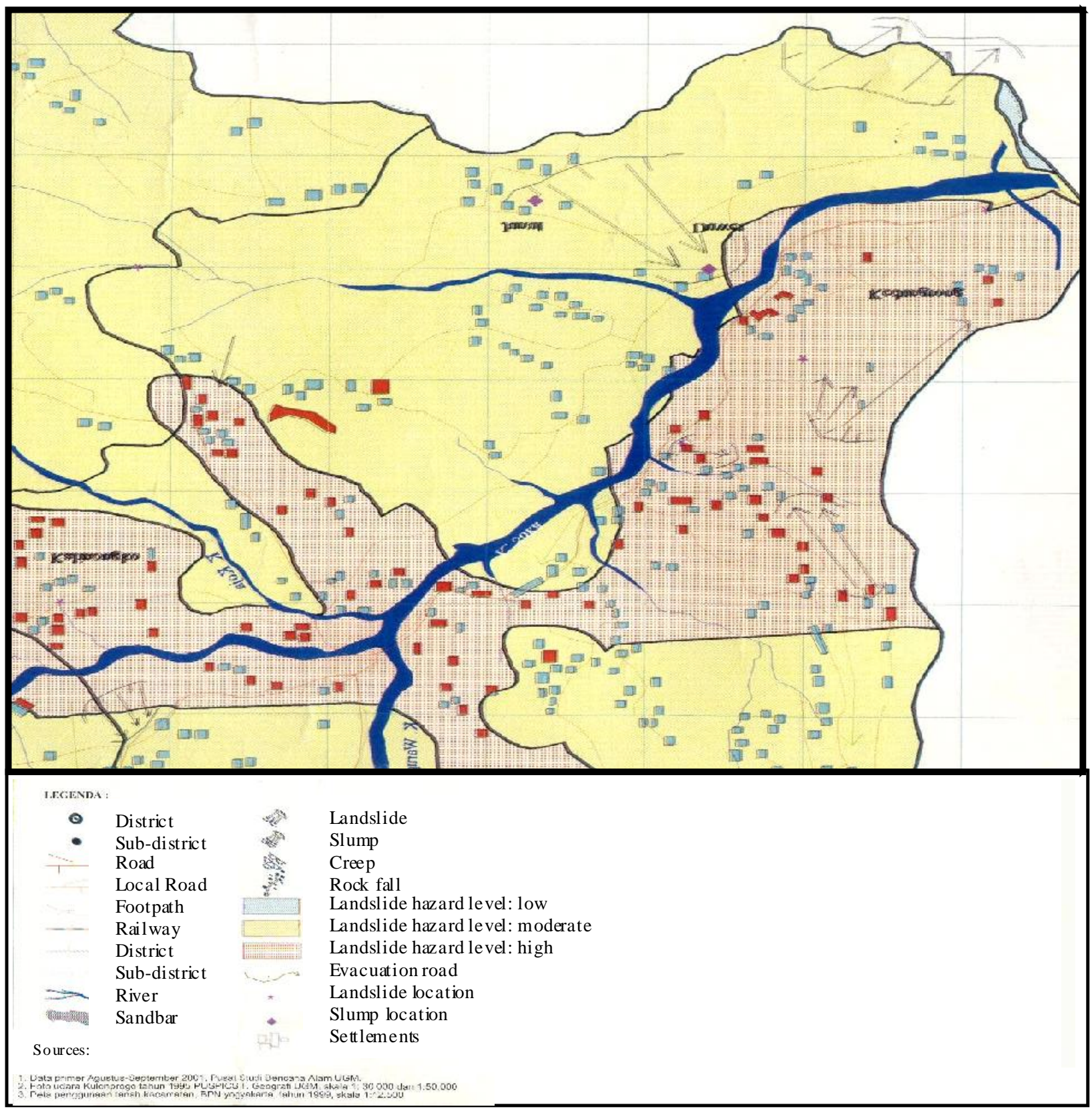

Figure 3. Distribusion Pattern of Population (Source: PSBA-UGM, 2001) 


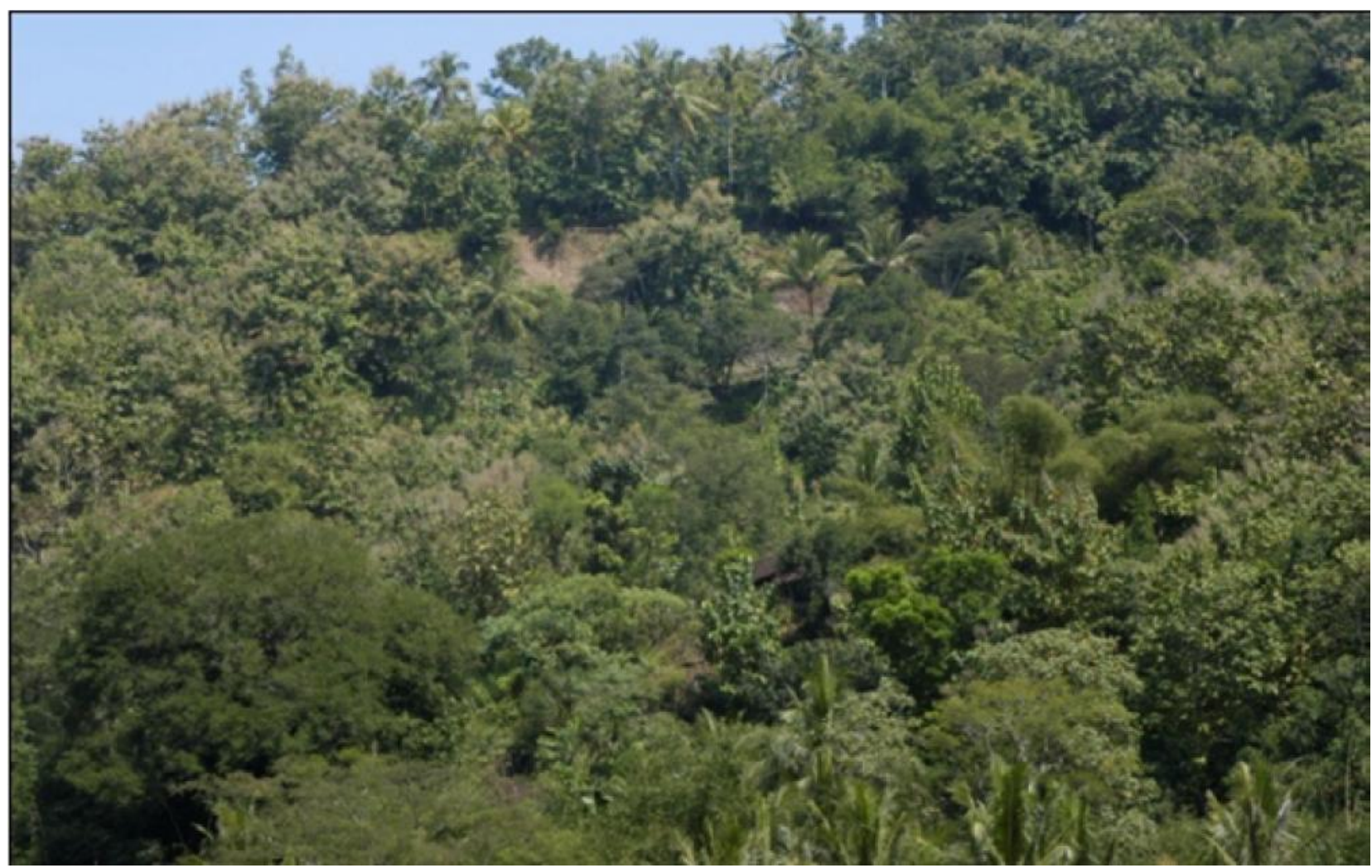

Figure 4. Land Cover of research Site

$14 \%$ continued their study in a higher level whereas the rest $(86 \%)$ of people only had elementary level of education.

\section{Community Responses to Policy of Spatial Planning}

In a response to anticipate and lessen the impacts of disaster in areas prone to landslide, The government of Kulonprogo Regency had developed spatial planning programs by issuing regional regulation no 1 year 2003. Based on that regulation and also the map of landslide potency with the scale of 1:25.000 issued by Pusat Studi Bencana Alam Universitas Gajah Mada (PSBA-UGM) Yogyakarta in 2001, it as shown that $96 \%$ of the research areas were included in areas prone to landslide with high risk level (Tabel 1).

Anticipation and map of disaster potency including level of vulnerability, level of risk and landslide signs had been sosialized to people. That map was also understood by the people living in the areas.

It could be said that sosialization of spatial planning and map of landslide potency to people worked well which was indicated from people' knowledge about areas prone to landslide and its signs. 95\% of the respondents from each category (men, women, young, adult and old people) stated that they had the knowledge about the landslide signs from the condition of the soil and the rainfall intensity. Furthermore, 99\% of the respondents stated that they know that they lived in areas prone to landslide. They (95\%) knew how to cope with and respond to these signs. It was due to their relationship with their big families since if they moved to other places, they would get social sanction from their families.

"I realize that the condition of the soil that I dig is very sensitive and prone to landslide, but If I have to move.....it's hard for me....yes, it's not easy, because leaving the big family is not easy"

Furthermore, it was strong in their mind that their house was a property and a heritage for their children and grandchildren. This opinion usually came from the old generation.

"We'got only this house that can be inherited to our children and gradchildren..............this house is also the place where I was born so that it should be taken care and inherited"

From the opinion above, it was shown that the shelter problem was not only a matter of realizing what kind of place they lived in but also there were another factors as a backgroud. Although sosialization of the spatial planning led to improvement of people's 
knowledge, it was still not enough to motivate them to leave their place. A house was not only a shelter but also a place for family relationship. Redfield in Wisadirana (2004) stated the similar condition about the it that although people of the village had experienced many changes, but still they were socially bounded by social values such as a value about togetherness which was known with a proverb "mangan ora mangan asal kumpul = having or not having meal in a life together with their own family is still better than in place far away from the family though that life is better". This mindset influenced much to the reason why they always wanted to survive in those areas.

Donie (2006) reported about how the people of Purwoharjo village interpreted their place. From 3 categories of respondents (young, adult and old), it was shown that the older people taught a house was a property that it should be taken care and inherited to the next generation regardless to the hazards of landslide cause they always tried hard to cope and avoid with.

" have been staying in this place for a long time and experience landslides for many times, but I still love living in here cause the sloping area can be deal with, it was too worthy leaving this place, I was born here and I want to die in here too although life and death are God's will"

Wisadirana (2004) in his analysis about people's interpretation and taught stated that nowadays the villagers still had the value of reliance to their condition, relied on farming for their lives and had personal relationship with their homeland and surrounding. Apparently people taught that everything that happened to them including landslide was a God's will and nobody could avoid any destinies from God. Poerwanto (2000) stated that this taught was called falistics that we could also find it in areas prone to

Tabel 1. Subdistrict, Level of Potency and Population in the research area

\begin{tabular}{clcc}
\hline No. & \multicolumn{1}{c}{ Subdistrict } & Level of Potency & Population \\
\hline 1. & Kedung Rong & 1 & 248 \\
2. & Bangunrejo & 2 & 349 \\
3. & Plarangan & 3 & 432 \\
4. & Taman & 4 & 322 \\
5. & Duwet & 5 & 270 \\
6. & Tukharjo & 6 & 367 \\
7. & Sendangrejo & 7 & 254 \\
\hline
\end{tabular}

Source : Monographi Purwoharjo Village, 2004

Tabel 2.Respondent Interpretations and Taughts of their houses

\begin{tabular}{|c|c|c|c|}
\hline \multirow[t]{2}{*}{ Category } & \multicolumn{3}{|c|}{ Age } \\
\hline & Young ( $<20$ year) & Adult (20-45 year) & Old (>45 year) \\
\hline Interpretation & - A shelter & $\begin{array}{l}\text { - A shelter } \\
\text { - A heritage of the } \\
\text { ancients }\end{array}$ & $\begin{array}{l}\text { - A heritage of } \\
\text { the ancients } \\
\text { - A property that } \\
\text { should be } \\
\text { taken care and } \\
\text { inherited }\end{array}$ \\
\hline Taught & $\begin{array}{l}\text { - They want to } \\
\text { move someday } \\
\text { - It depends on their } \\
\text { parents }\end{array}$ & $\begin{array}{l}\text { - There is a } \\
\text { possibility for them } \\
\text { to move } \\
\text { - They survive }\end{array}$ & - They survive \\
\hline
\end{tabular}

Source: Donie, 2006 
eruption as reported by Minsarwati (2004) in her book 'Mitos Merapi dan Kearifan Lokal dalam masyarakat Jawa $=$ Myths of Merapi and Local wisdoms of Javanese People'.

\section{Community Response to The Policy of Migration}

Another policy issued by the government was the policy about migration of people from an area prone to landslide to a safe area. There were 2 ways: translocation and transmigration both spontaneous and public transmigration.

The first place which was relocated was Dukuh Klepu, a small part of Purwoharjo Village having some flat areas. It happened in 2001 when there was a landslide in Dukuh Kedung Rong by relocating 10 families, both who were the victims and the families with the landslide potency. This unable to get any good response although it was only $3 \mathrm{~km}$ from their previous houses and from those 10 families, 7 unable to survive and returned to their houses.

The second relocation was for Dukuh Krian, Banjarharum Village (10 km from Purwoharjo
Village). It happened when there was a landslide in Dukuh Duwet by relocating 6 families but 1 unable to survive. The reason why they unable to survive were that they were pretty far from their field and not comfortable living in a rapid neighborhood (Figure 4 and 5).

Their previous resident was pretty large and one house to another house was not so rapid (Figure 4). Moreover, there were a large yard for each house which had vegetables and herbs. On the contrary, the new place was only $4 \times 6 \mathrm{~m}^{2}$ and one house to another was only $1 \mathrm{~m}$ away. Each house is not equiped with front yard or back yard as well (Figure 5).

\section{"I can even hear the whispering neighbor"}

In 2001, the government provided transmigration program to the people in Bengkulu province and 7 families from Dukuh Kedung Rong joined it. They could survive for only 1 year and came back again to their previous place. The reason was that they felt hard to live in such a virgin area where they had to work much harder than before so that they decided

Tabel 3. Migration of Landslide Victims in Purwoharjo, Kulonprogo

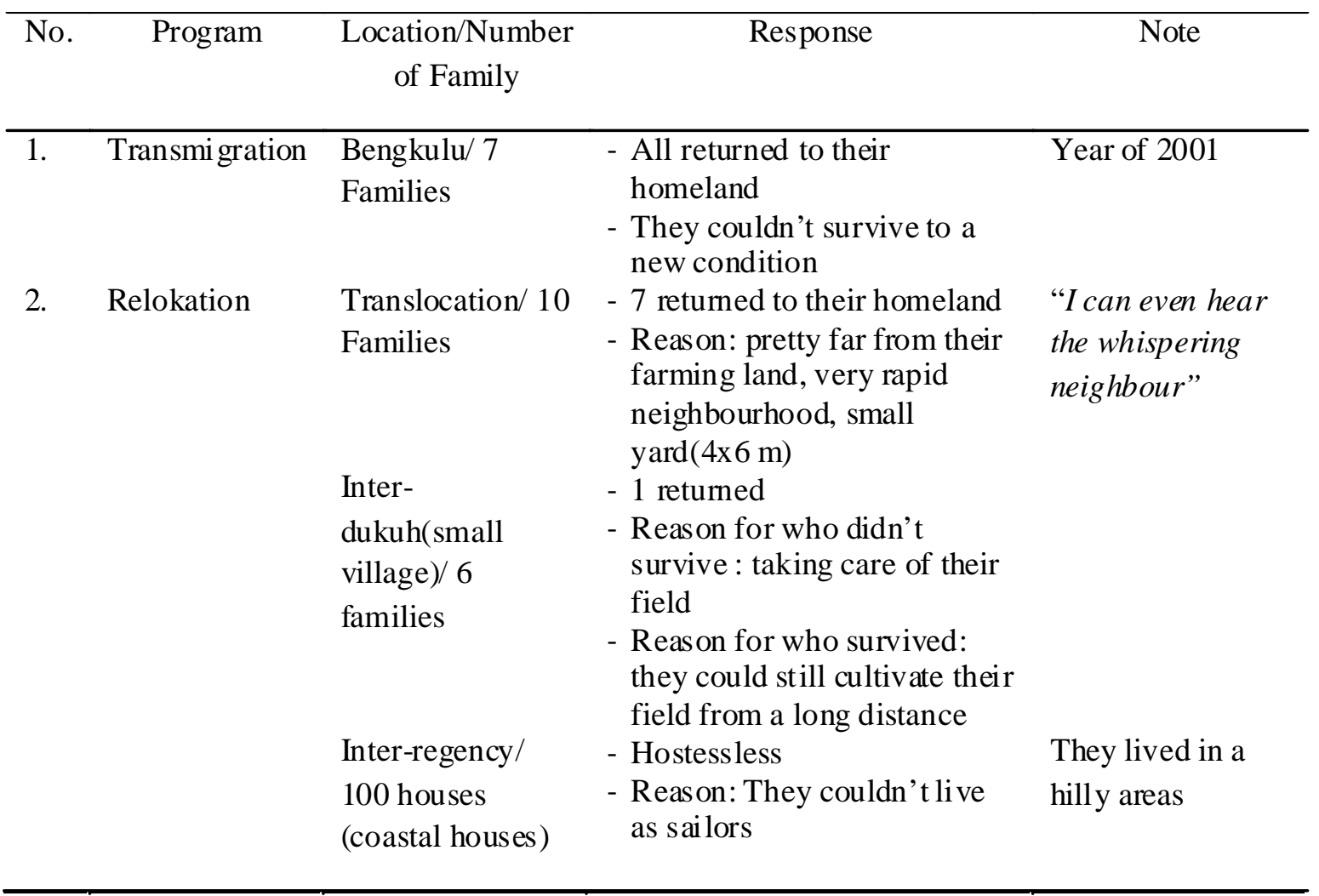

Source: Donie, 2006 
to return to their previous place.

"their home is a place that can not be separated from their lives for now.... if they move to another place, it means that they must start their lives from the beginning."

Problem of unemployement was always not something easy to solve. People who survived feared of the same thing that they would not get the same job. Therefore, relocation had a strong relationship with the employement and social culture. Riady (1994) stated the similar thing about this circumtance with his reasearch that in Transmigration area in Kota Bangun, East Borneo, the adaptaion level of the people was low which indicated more families returned to their previous place. This was because the market orientation, their main jobs and life needs.

\section{Community Response to the prohibition of Cultivating Annual Crops}

Another policy issued by the government was the prohibition of cultivating annual crops on a sloping land due to the landslide. This policy had a correlationship with what their ancestors had inherited. People did not know why their ancestors forbade them cultivating such annual crops, but since it was a heritage they just did it. They even could not explain well and it became such a 'taboo' to cultivate annual crops on a sloping areas.

Time went by and people changed so that such a heritage would not be something very important for them. They began cultivating vegetables and cassava. This because people's life need increased rapidly and it was not correlevant with the land that they could use to cultivate. If cultivating such crops were prohibited, they would have difficulty in finding other jobs. Furthermore, cutting a slope was a prohibition as well although they did it for making a shelter.

Chambers (1983) stated that poverty has influenced much to people in fulifilling their needs; both the need for safety and the need for food. The prohibition policy of planting annual crops on sloping lands was insufficiently responded properly. This was caused

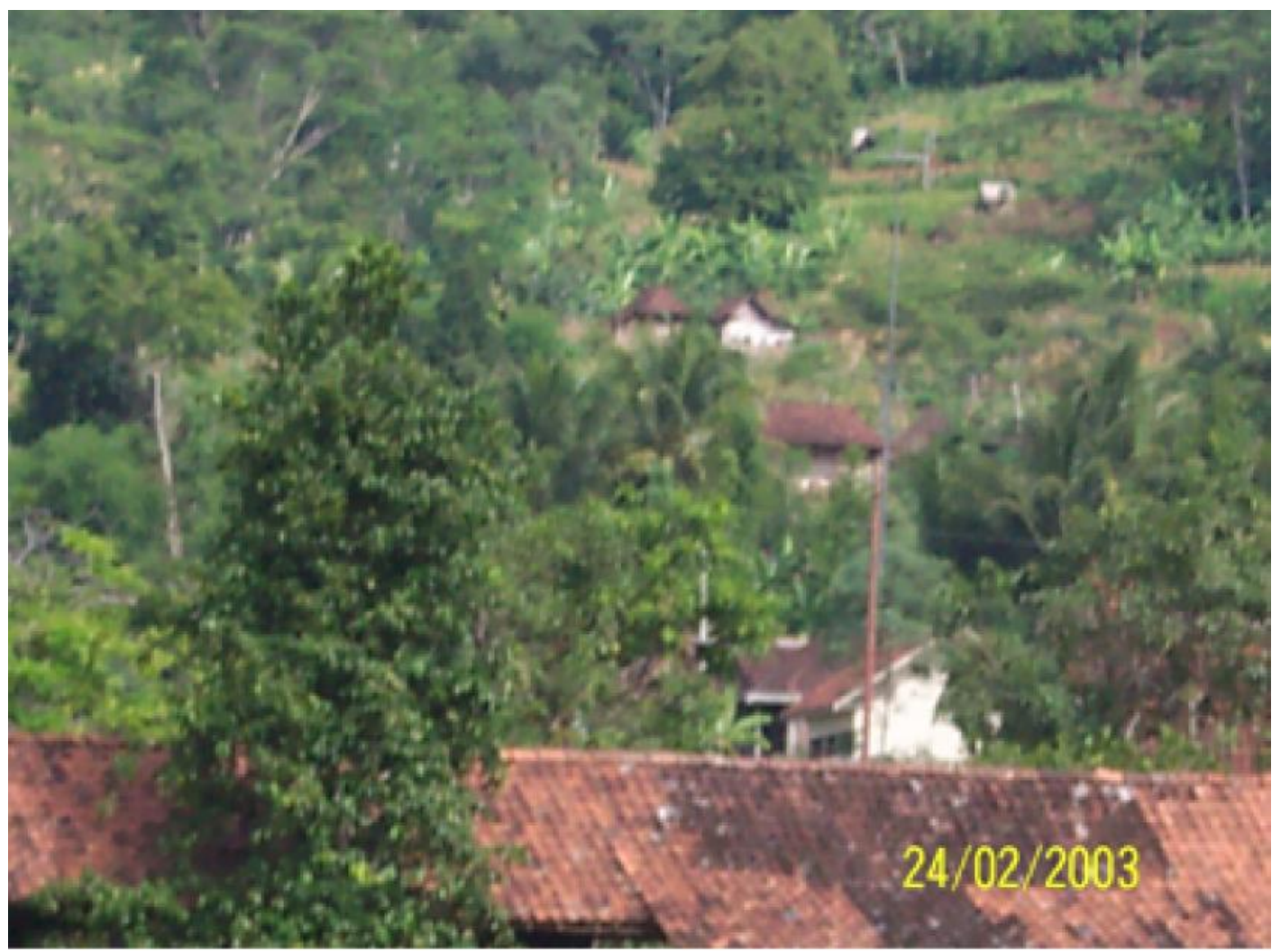

Figure 4. Residential condition before relocation 


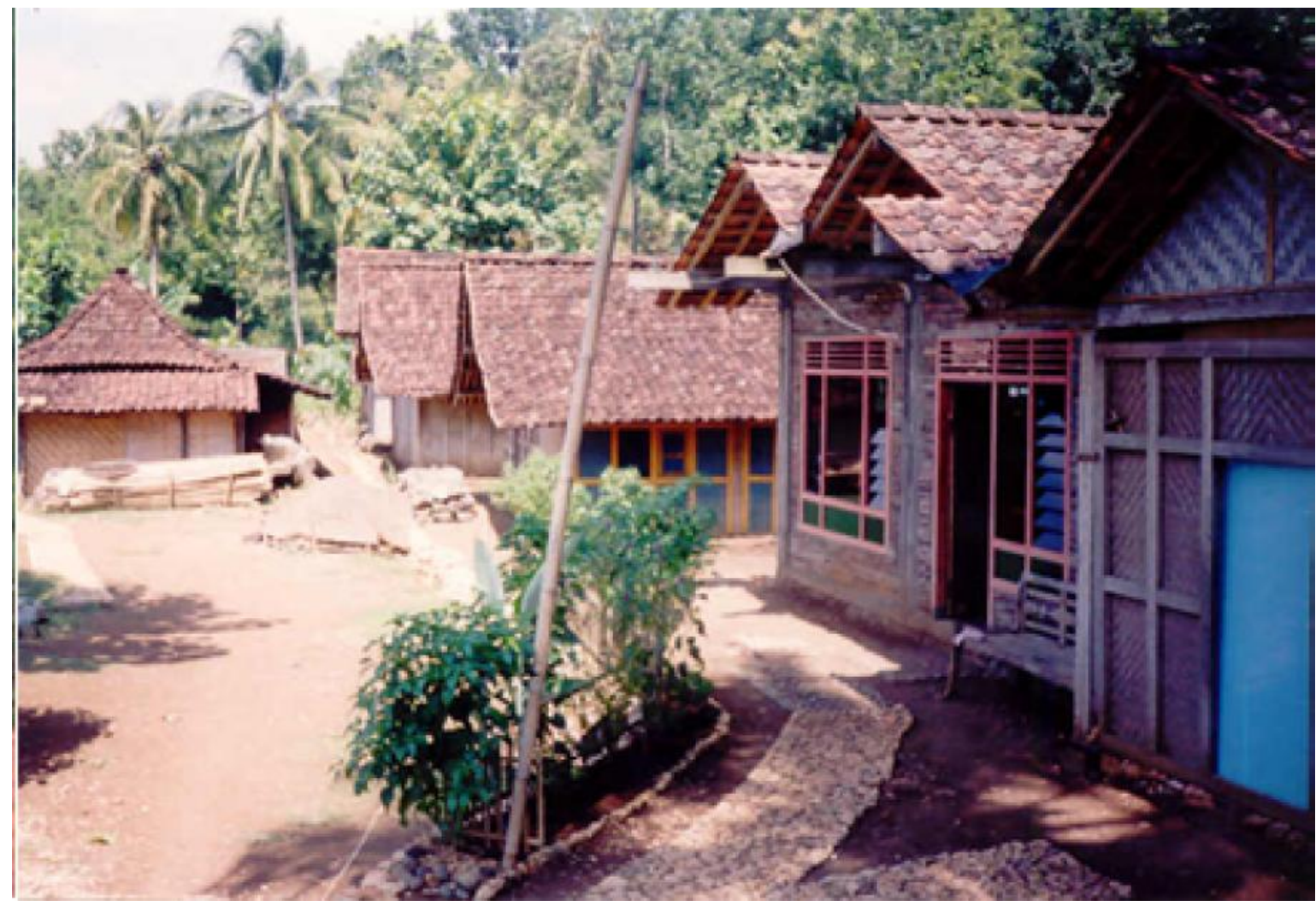

Figure 5. pattern after relocation

by the insistence of community basic-needs to the land for their livelihood. The phenomenon happened as well in 1998 when there was a 'reform movement'. There was an 'anomali' in people circumtance that they could do anything that they want. People did not have any fear on anything including sacred places or sacred jungle. It showed that in any hard circumtance, people could do anything including breaking social values. In his research Sartohadi (2008) stated that to respond to and to cope with the landslide caused by human activities, people should be empowered.

\section{Conclusion}

1. The regional policies of Kulonprogo Regency for the people in areas prone to landslide were the policy of spatial planning, the policy of relocation and the policy of physical rehabilitation and prohibition of cultivating annual crops. Those had already been published to the people as well.

2. Policies of spatial planning and a map of landslide potency were well-done published which was shown by an improvement in people's knowledge about the hazards of landslide. Almost all respondents knew well that they lived in hilly areas prone to landslides, and they knew how to cope with and respond to these signs.

3. It was difficult for the people to move to other safer places since their experiences taught them that a new place unable make their lives better, both in terms of livelihood as well as in terms of their socialculture life.

4. The prohibition policy of planting annual crops on sloping lands was insufficiently responded properly. This was caused by the insistence of community basicneeds to the land for their livelihood.

5. Implementation of the policies so far could not accommodate yet to social-culture and interests of the community. In addition, factors of poverty, lack of land ownership, unavailability of employment, low educational level, and internalized culture inherent "mangan ora mangan asal kumpul = having or not having meal in a life together with their own family is still better than in place far away from the family though that life is better" influenced the community willingness to live in their new settlement. 


\section{References}

Anonimus, 2003. Monografi Desa Purwoharjo, Kecamatan Samigaluh, Kabupaten Kulonprogo, Tahun 2003.

Chambers, R., 1983. Pembangunan Masyarakat Desa: Mulai dari Belakang. LP3ES.

Donie, S., 2006. Masyarakat Yang Tinggal Di Daerah Rawan Longsor: Interpretasi, Penyebab dan Strategi Adaptasi. Thesis, Universitas Gajahmada, Yogyakarta.

Hindaryoen, N., 2000. Kondisi Lingkungan Kian Rapuh: Dari Musibah Banjir dan Tanah Longsor di Jawa Tengah. Kompas 20-11-2000.

Hirnawan, F., 1994. Pemahaman Sistem Dinamis Kestabilan Lereng untuk Mitigasi Kebencanaan Longsor. Disampaikan pada Simposium Nasional Mitigasi Bencana Alam di UGM 16-17 September 1994.

Kartiwati, D., 2003. Ditemukan 13 Lokasi Baru Rawan Longsor di Purworejo. Harian Kompas, Desember 2003. 